\title{
Lesbian Representation In Bengkulu City (Studies In Paired Ra And Ad)
}

\section{Representasi Lesbian Di Kota Bengkulu (Studi Pada Pasangan Ra Dan Ad)}

\author{
Nadia Amanda1); Anis Endang2); Bayu Risdiyanto3) \\ 1,2,3) Department of Communication, faculty Of Social sciences, Universitas Dehasen \\ Bengkulu \\ Email: anisendangsm@gmail.com
}

\begin{abstract}
How to Cite :
Nadia, Amanda, Endang,Anis \& Risdiyanto, Bayu (2021). Lesbian Representation In Bengkulu City (Studies In Paired Ra And Ad). Sengkuni Journal: Social Sciences and Humanities Vol. 2 No. 1 2021 page: 53-61. DOI: https://doi.org/10.37638/sengkuni.2.1.53-61
\end{abstract}

\section{ARTICLE HISTORY}

Received [23 April 2021]

Revised [03 May 2021]

Accepted [15 June 2021]

KEYWORDS
Representation, Lesbian,
Bengkulu City.

This is an open access article under the $\underline{C C}-B Y-S A$ license

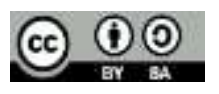

\section{ABSTRAK}

Tujuan dari penelitian ini untuk mengetahui representasi lesbian di Kota Bengkulu. Representasi tersebut dilihat dari realitas, representasi, dan ideologi terkait latar belakang, perilaku, pandangan para lesbian. Penelitian ini menggunakan metode penelitian kualitatif dengan pendekatan studi kasus. Adapun hasil penelitian ini (1) terkait realitas informan menjadi lesbian karena faktor lingkungan, kurangnya pengawasan keluarga sehingga mereka terjerumus menjadi seorang lesbian. (2) terkait representasi bahwa lesbian mengakui tidak ada simbol-simbol khusus yang mereka gunakan. (3) dan terakhir terkait ideologi informan menyadari bahwa lesbian merupakan penyimpangan sosial, pergaulan yang salah.

\section{ABSTRACT}

The purpose of this study was to determine the representation of lesbians in Bengkulu City. This representation is seen from the reality, representation, and ideology related to the background, behavior and views of the lesbians. This study uses a qualitative research method with a case study approach. The results of this study (1) relate to the reality of informants becoming lesbians due to environmental factors, lack of family supervision so that they fall into lesbians. (2) related to the representation that lesbians admit that there are no special symbols that they use. (3) and finally related to the ideology, the informants realized that lesbian is a social deviation, wrong association. 


\section{PENDAHULUAN}

Sebagian orang menganggap ada dua bagian dalam kehidupan bersosialisasi dalam masyarakat yaitu kaum hitam dan kaum putih. Kaum putih adalah masyarakat dari kelompok terpelajar dan baik-baik, sedangkan kaum hitam adalah sampah masyarakat karena pelanggaran dan penyimpangan yang dibuatnya. Namun tidak banyak yang mengetahui terdapat kaum abu-abu, dimana mereka nampak normal dan baik-baik saja. Tetapi, perilakunya sedikit berbeda sehingga dikatakan sebagai masalah sosial di tengah masyarakat (Soekanto, 2004: 381). Hal ini berarti bahwa di masyarakat terdapat banyak ragam dari setiap perilaku masyarakat. Bukan hanya strata sosial atau status sosial yang berbeda-beda namun perilaku juga.

Diciptakan-Nya manusia berpasang-pasangan ialah pria serta wanita sehingga mampu membangun suatu keluarga yang serasi (Budiarty, 2011). Idealnya pria berpasangan dengan wanita sehingga membentuk suatu ikatan. Dalam suatu keluarga pria berfungsi selaku kepala rumah tangga serta wanita selaku ibu rumah tangga yang tugasnya mengurus rumah serta mendidik anak-anak. Perihal tersebut sesuai dengan jenis kelamin serta kedudukannya. Manusia baik pria ataupun wanita melaksanakan tugasnya sesuai kodrat yang diberikan pencipta. Dalam hal kehidupan sosial manusia tak lepas dari masalah kehidupan. Salah satu masalah yang biasanya ada di masyarakat yaitu masalah Fenomena Lesbian ialah salah satu kejadian yang sangat familiar untuk dibahas dalam kehidupan manusia. Sudah terdapat Lesbian dari sejarah mesir kuno. Keberadaan kalangan Lesbian, di barat (Eropa) tidak hanya dilarang oleh warga serta institusi agama, namun pula dilarang secara hukum oleh suatu negeri. Pada tahun 1990an sebutan Lesbian muncul (Papilaya, 2016).

Pelaku Lesbian terus bertambah. Berdasarkan pendataan yang dilakukan Kantong Informasi Pemberdayaan Kesehatan Adiksi (KIPAS) Bengkulu, sepanjang tahun 2017 lalu ada 3.754 orang yang menyukai sesama jenis. Direktur Kipas Bengkulu, Merli Yuanda mengungkapkan bahwa perilaku menyukai sejenis yang terjadi di Bengkulu saat ini termasuk tinggi. Untuk itu, Kipas melakukan gerakan untuk mengurangi penderita HIV/AIDS di kelompok Lesbian, Hal ini karena Lesbian, merupakan penyumbang tertinggi kedua HIV setelah pekerja seks. Pemerintah Provinsi Bengkulu lewat Dinas Kominfo serta Statistik Provinsi Bengkulu sudah merespon serta menyikapi maraknya konten serta akun Lesbian,di Media Sosial berbasis internet. Berkenaan perihal tersebut Kepala Dinas Kominfo serta Statistik Provinsi Bengkulu menyikapi untuk dapat ditindaklanjuti penangkalan serta penindakan. Departemen Kominfo RI sebagai pemegang hukum serta kewenangan memblokir/menutup konten-konten serta akun di media sosial yang berbau Lesbian,serta sudah melaksanakan koordinasi serta komunikasi dengan Bidang Humas Polda Bengkulu untuk penindakan konten serta akun Lesbian, di media sosial. Sampai Oktober 2018 ini, departemen Kominfo sudah melaksanakan pemblokiran terhadap $\geq 890$ ribu web yg melanggar undang-undang, 80 $\%$ antara lain merupakan web pornografi seperti LGBT.

Grup facebook yang merupakan orang-orang penyuka sesama jenis atau Lesbian, diselidiki oleh Polda Bengkulu. Ironisnya, anggota grub itu sebagian besar merupakan masyarakat Provinsi Bengkulu. Kabid Humas Polda Bengkulu, AKBP Sudarno berkata regu cyber troops Polda Bengkulu dikala ini sudah menyelidiki sekitar 10 grup facebook. Perihal ini dilakukan setelah adanya keluhan warga resah adanya kegiatan grup LGBT yang aktif di media sosial itu. Anggotanya sudah menggapai 1.0002.000 orang. Grup tersebut dikenal aktif dalam memposting konten bertabiat pornografi serta obrolannya juga bersifat dewasa. Menghindari penyebaran serta terus menjadi berkembangnya group Lesbian, di Provinsi Bengkulu, diharapkan kerjasamanya seperti media, guru, warga, tokoh masyarakat, tokoh agama untuk turut aktif dalam mengatasi 
pertumbuhan Lesbian. Terdapat sebagian aspek pemicu orang cenderung untuk jadi bagian dari Lesbian, antara lain keluarga, pengalaman aaupun trauma yang mendalam pada waktu kanak-kanak misalnya dikasari oleh ayah/bunda akibatnya anak yang sudah dikasari merasa benci terhadap orang tersebut. tidak hanya itu, pergaulan serta tempat tinggal, pergeseran norma susila serta minimnya kontrol sosial yang terdapat di kalangan masyarakat (Sa'dan, 2016).

Hal tersebut membuktikan peran orangtua terhadap anak sangat lah penting sehingga anak tidak salah dalam bergaul, orangtua serta anak harus terbuka. Selain itu pergaulan di masyarakat juga harus diperhatikan sehingga tidak salah bergaul. Akibat yang ditimbulkan dengan adanya gaya hidup seksual Lesbian, yaitu penularan penyakit HIV/ AIDS. Selain itu, rentan akan penyakit kelamin lainnya yang sangat berdampak pada kesehatan. Hubungan gay atau hubungan seks sesama laki-laki lebih mudah penularan penyakit. Dalam riset Jasruddin, Nurdelia serta Daud di Makassar dipaparkan sikap penyimpangan intim semacam transgender dikira selaku sesuatu prilaku menyimpang dari nilai serta norma sosial yang dianut oleh warga. Terpaut permasalahan perilaku Lesbian, dapat memberikan wawasan tentang Lesbian

Lesbian ialah kalangan wanita yang menyayangi ataupun memiliki hasrat intim sesama jenisnya. Gay ialah kalangan pria yang menyayangi ataupun merasakan rangsangan intim sesama jenisnya. Tidak hanya itu biseksual ialah orientasi intim antara seseorang laki-laki/perempuan yang menggemari 2 tipe kelamin baik lakilaki/perempuan. Sebaliknya Transgender ialah orang yang mengubah tipe kelamin yang idamkan dengan jalur pembedahan, sebaliknya transeksual ialah orang yang sudah melaksanakan pembedahan pengantian kelamin (Rizal, 2016). Sehingga dapat kita tahu bahwa Lesbian berbeda dengan gay, transgender dan biseksual. Lesbian ialah fenomena sosial yang melanggar norma serta keberadaannya yang disadari oleh warga yang memunculkan bermacam berbagai respon oleh lingkungannya. Tak heran jika terjadinya penolakan dari lingkungan sekitar dan membuat para Lesbian malu buat menampilkan bukti diri intim mereka yang sesungguhnya sehingga membatasi mereka untuk berkomunikasi dalam interaksi sehari-hari. Masyarakat dan Lesbian membuat jarak pemisah keberadaannya karena masyarakat menganggap ketidakwajaran hasrat seksual dan pola hidup kaum Lesbian.

Baik Lesbian, merupakan masalah sosial yang melanggar normal dan harus dicegah penyebarannya di masyarakat. Bukan cuma di kota-kota besar semacam jakarta tetapi pula di daerah-daerah lain. Berdasarkan fenomena Lesbian, tak heran ada orang melakukan reprentasi terhadap penyimpangan tersebut. Berdasarkan hasil observasi peneliti yang dilakukan didapatkan bahwa terdapat Lesbian di kota Bengkulu, Lesbian tersebut disebabkan karena pergaulan yang salah oleh para Lesbian sehingga penyimpangan tersebut terjadi.Representasi secara umum merupakan cara bagaimana seseorang atau sesuatu ditampilkan, baik itu individu, kelompok, konsep, atau pun sebuah ide. Representasi tidak hanya membahas mengenai tampilan fisik seseorang, tetapi representasi lebih jauh menyimpan makna di baliknya. Istilah representasi dalam ilmu bahasa adalah suatu proses pengungkapan makna yang ada di balik penggunaan bahasa. Seseorang yang mampu mengungkapkan konsep, pikiran, ide / gagasan melalui penggunaan bahasa (Hall, 1997).

\section{LANDASAN TEORI}

Representasi merupakan suatu konsep yang biasa digunakan dalam proses sosial pemaknaan lewat media semacam: diskusi, tulisan, video, film, gambar serta lain sebagainya. Pemahaman tentang representasi senantiasa terdapat perubahan dari konsep atau pemahaman sebelumnya. Elemen teknis dalam bahasa semacam kata, 
kalimat, serta sebagainya. Sebaliknya dalam tv (televisi) semacam kamera, tata sinar, editing, music serta sebagainya. Kemudian ditampilkan ke sebuah objek dalam wujud: keperibadian, narasi, setting, diskusi serta sebagainya (Eriyanto, 2008:115).

Representasi dimaksud selaku sesuatu proses perekaman gagasan ataupun pemikiran, pengetahuan, ataupun pesan secara raga. Gambar, suara, dan lain sebagainya dijadikan sebuah tanda untuk mendefinisikan apa yang dimaksud dengan representasi yang kemudian diharapkan mampu di tampilkan ulang dari suatu yang diserap, diindra, dibayangkan, ataupun dialami dalam bentuk raga. Sebuah penanda dalam semiotika untuk representasi dinyatakan dalam wujud $X$, petanda dalam semiotika baik itu jelas atau tidak dinyatakan dalam wujud $Y$, serta arti secara potensial dapat diambil dari representasi yang umumnya disimbolkan dalam $(X=Y)$, dalam suatu lingkup budaya tertentu, diucap selaku signifikasi ataupun sistem penandaan. (Danesi : $2012: 3$ ). Representasi bekerja pada ikatan ciri serta arti. Seperti yang telah dijelaskan sebelumnya bahwa konsep representasi sendiri dapat berubah-ubah. Representasi berubah-ubah akibat arti yang juga berubah - ubah. Tiap waktu terjalin proses negoisasi dalam pemaknaan. Jadi bisa disimpulkan bahwa representasi merupakan proses yang terus berkembang seiring dengan kemampuan intelektual dari pengguna tanda yaitu manusia itu sendiri. Representasi ialah sebuah proses usaha pembaruan. dari pemikiran ataupun uraian baru yang menciptakan pemaknaan baru, ataupun dapat pula dikatakan sebagai suatu bentuk pertumbuhan pembaruan pemikiran manusia itu sendiri. (Wibowo, 2011:123).

Konsep mengenai representasi dapat berganti, sebab senantiasa terdapat uraian baru dari konsep sudah pernah ada. Representasi adalah hasil dari penandaan, yaitu hasil untuk membuat pemaknaan suatu (Juliastuti, 2000:1). "Representasi merupakan penciptaan arti lewat bahasa" (Hall, 1997:16). Representasi ialah hasil dari sesuatu pemaknaan yang disampaikan dalam bentuk narasi. Untuk mempresentasikan sesuatu hal yang perlu kita lakukan adalah menggambarkan sesuatu hal kemudian kita deskripsikan atau kita bayangkan dengan menyatukan perasaan dan pikiran kita. (Hall, 1997:19). Dalam memandang, manusia mempunyai penafsirannya berbeda-beda satu sama lain. Perihal tersebut mencuat sebab terdapatnya pola pemikiran ataupun pendapat akan sesuatu yang digambarkan berbeda. Uraian tentang penafsiran itu biasa disebut representasi. Representasi ialah suatu aksi yang memperkenalkan suatu pengertian ataupun pemikiran melalui sesuatu ataupun objek yang lain diluar dirinya, umumnya dalam wujud ciri ataupun simbol (Piliang, 2003: 24). Danesi (2012) menjelaskan representasi merupakan pemakaian ciri yang digunakan untuk menghubungkan, menggambarkan, memotret, ataupun menciptakan suatu yang dilihat, diindera dalam wujud raga tertentu. Sehingga bisa disimpulkan terkait representasi ialah hasil pemikiran orang hasil panca indera dari penggunaan tanda.

Representasi ialah wujud pembaruhan terhadap seluruh aspek kenyataan atau realitas yang sesungguhnya seperti warga, objek, kejadian, sampai bukti diri budaya menurut Hall. (Juliastuti, 2000:6), dimana representasi merupakan salah satu praktek berarti yang menciptakan kebudayaan yang berpengaruh bagi masyarakat. Orang dikatakan berasal dari kebudayaan yang sama jika manusia-manusia yang terdapat satu kelompok yang sama membagi pengalaman yang sama, membagi kode-kode kebudayaan yang sama, berdialog dalam bahasa yang sama, dan silih berbagi konsepkonsep yang sama. Perihal pendapat bahwa representasi wajib dimengerti dari kedudukan aktif serta kreatif orang tentang memaknai suatu perihal. Representasi bukan Cuma mengaitkan bagaimana bukti diri budaya melakukan pembaruhan ataupun konstruksikan di dalam suatu bacaan tetapi pula dikonstruksikan di dalam proses 
penciptaan oleh masyakarat yang menggunakan nilai-nilai budaya.

Bagi Hall terdapat 2 proses terbentuknya representasi ialah representasi mental, konsep ini menimpa suatu yang kita pikirkan tiap orang. Representasi mental masih merupakan sesuatu yang abstrak. Kedua, 'bahasa' yang berfungsi berarti dalam proses konstruksi sebab berperan buat menerjemahkan apa yang kita pikirkan. Terdapat 2 proses ini, menerangkan representasi tidak begitu saja ada, namun lewat tahapan dari terdapatnya anggapan dalam benak serta setelah itu diutarakan lewat bahasa, baik tertulis ataupun lisan. Jadi ininya kedua konsep tersebut sangat berkaitan. Sebab dengan terdapat pemikiran ataupun uraian kita terhadap suatu perihal hinggal perihal tersebut wajib di gambarkan ataupun dibayangkan setelah itu diinformasikan perkata ataupun yang kita pakai. Ikatan antara (peta konseptual) serta (bahasa simbol) merupakan perihal terpenting dari penciptaan arti melalui bahasa, baik secara internasional dan nasional. Proses yang menghubungkan keduanya secara bertepatan dinamakan representasi.

\section{METODE PENELITIAN}

Penelitian ini memakai metode penelitian kualitatif dengan pendekatan studi kasus sebab informan dalam penelitian ini sfesifik pada wanita Lesbian dari responden. Serta pendekatan yang digunakan merupakan pendekatan kualitatif ialah sesuatu tata cara yang digunakan untuk menciptakan pengetahuan terhadap sesuatu sikap, fenomena, kejadian permasalahan ataupun kondisi tertentu.

Dalam penelitian ini, peneliti memakai analisis interaksi, dimana komponen reduksi informasi serta sajian informasi dilakukan bersamaan dengan proses pengumpulan data. Tiga tahap dalam menganalisa informasi, ialah:

Data Reduction (Reduksi Data) Data reduction ataupun reduksi informasi merupakan aktivitas memilah perihal pokok yang difokuskan pada hal-hal yang berarti serta membuang perihal yang tidak berarti ataupun dapat dikatakan sesuatu aktivitas merangkum perihal yang berarti saja. Dengan mereduksi kita sanggup menerangkan lebih rinci sehingga bisa mengumpulkan informasi dengan gampang. Reduksi informasi pula bisa dibantu dengan memakai perlengkapan elektronik. (Sugiyono, 2017:123).

Data Display (Penyajian Data) aktivitas berikutnya merupakan mendisplay informasi. Dalam penelitian kualitatif informasi yang dicoba dalam wujud cerminan objek penelitian serta uraian pendek menimpa objek yang diteliti. Uraian pendek tersebut diharapkan bisa membagikan cerminan sesuatu objek yang diteliti.

Terakhir penarikan Kesimpulan, dalam penelitian kualitatif merupakan penarikan kesimpulan atau biasa disebut juga verifikasi. Apabila suatu penelitian tidak ditemukannya pendukung dan bersifat berubah berarti kesimpulan tersebut termasuk dalam kesimpulan sementara. Namun apabila kesimpulan yang dikemukakan pada sesi ini, didukung oleh bukti-bukti yang valid tidak berubah-ubah dikala peneliti kembali ke lapangan mengumpulkan informasi, hingga kesimpulan yang dikemukakan ialah kredibel (Sukmadinata, 2007).

\section{HASIL DAN PEMBAHASAN}

Dalam kehidupan masyarakat yang berlandaskan pada norma dan budaya pasangan harus berlawan jenis, menjadi homoseksual (Lesbian) merupakan suatu bentuk penyimpangan. Namun begitu, ada saja anggota masyarakat yang menjadi Lesbian. Bersumber pada hasil wawancara dengan informan bisa diketahui bahwa pemicu informan menjadi Lesbian sebagai berikut: 
Menurut RA menjelaskan bahwa:

"saya menjadi Lesbian karena faktor pergaulan, salah mencari teman. Saya menjadi Lesbian berperan sebagai perempuan" (Jumat, 28 Agustus 2020)

Hal serupa juga dijelaskan AD :

"karena merantau, salah mencari teman. Teman dari media sosial. Membuat terjerumus menjadi seorang Lesbian, saya menjadi Lesbian berperan sebagai seorang laki-laki." (Jumat,28 Agustus 2020)

Dari hasil wawancara dapat dikatakan bahwa RA dan AD menjadi Lesbian karena faktor lingkungan. Faktor lingkungan di sini karena salah mencari teman dalam bergaul. Jauh dari keluarga tidak ada pengawasan dari keluarga membuat mereka menjadi Lesbian. Berbagai sebutan dan label negatif yang dicapkan kepada para Lesbian membuat mereka sulit untuk mengungkapkan diri bahwa mereka adalah Lesbian. Berdasarkan hasil wawancara dengan AD didapat bahwa:

"Di Bengkulu saya tinggal dengan oom dan tante saya. Karena merasa sendiri tidak punya teman saya mencari teman di media sosial. Awalnya ya seperti teman biasa. Tapi lama-kelamaan saya merasa sedikit berbeda dengan pasangan Lesbian saya. Perasaan nyaman sehingga salah dalam memilih teman. Panggilan kami juga seperti panggilan wajar biasa seperti cuy dan say. Keluarga saya tidak mengetahui pergaulan saya di bengkulu dan begitupun oom dan tante saya. Mereka tahu kalo saya membawa teman ke rumah sebagai teman biasa." (Jumat, 28 Agustus 2020)

Karena jauh dari keluarga dan tinggal bersama keluarga paman dan bibi di Kota Bengkulu AD menjadi Lesbian tidak diketahui oleh pihak orangtua begitupun keluarganya di Bengkulu.Hasil wawancara dengan RA:"saya menjadi Lesbian diam-diam, keluarga saya tidak mengetahui saya seorang Lesbian. Begitu juga masyarakat di lingkungan saya tinggal. Saya bersama pasangan saya juga memanggil pasangan seperti orang biasa say dan cuy. Cara berpakaian saya juga biasa, yaitu memakai levis dan celanacelana." (Jumat, 28 Agustus 2020)Penulis juga menanyakan mengenai pandangan apa itu Lesbian, pasangan Lesbian mereka, dan apa yang biasa mereka lakukan kepada pasangan di masyarakat? Menurut pendapat AD bahwa: "Lesbian adalah penyuka sesama jenis, saya mempunyai pasangan Lesbian, biasanya saya jalan-jalan ke mall, dan lain-lain, masyarakat masih menilai seperti teman dekat atau sahabat" (Jumat,28 Agustus 2020) Pedapat serupa juga disampaikan oleh RA bahwa: "Lesbian penyuka wanita sejenis. Saya mempunyai pasangan lain jenis dan pasangan sejenis. Saya 
dengan pasangan Lesbian saya untuk senang-senang saja, jalan-jalan, makan, nonton karena pasangan saya tidak satu daerah dengan saya" (Jumat,28 Agustus 2020)

Dari wawancara dengan $\mathrm{RA}$, dan $\mathrm{AD}$ diketahui bahwa mereka dalam berhubungan dengan sesama Lesbian tidak diketahui oleh keluarga, teman serta orangorang di lingkungan tempat tinggal. Mereka menampakkan diri mereka seperti orangorang biasa. Dengan menjadikan teman-teman Lesbian sebagai sahabat mereka. Sedangkan mengenai aktivitas Lesbian di kota Bengkulu, mereka mengatakan bahwa kegiatan mereka hanya untuk mencari kesenangan saja. Biasanya mereka keluar dengan pasangan untuk mencari hiburan.

Uraian utama dari teori representasi merupakan penyampaian suatu yang berarti kepada orang lain. Sebaliknya Lesbian merupakan wanita yang mempunyai hasrat seksual serta emosi kepada wanita lain. Ada banyak teori yang sempat dikemukakan dalam mengemukakan tentang faktor-faktor pemicu Lesbian. Perihal ini diakibatkan keunikan jiwa manusia serta ikatan timbal balik dengan latar belakangnya, lingkungannya dan pertumbuhan sosialnya. Tetapi biasanya orang meninjau pemicu dari sebagian segi kehidupan antara lain:

1. Pengaruh kondisi keluarga serta keadaan hubungan orang tua

Pengaruh keadaan keluarga ialah, ikatan yang terjalin antara orang tua (bapak atau ibu) yang kurang harmonis antara kedua belah pihak antara bapak dan Ibu seperti kerap cekcok, atau terjadi keributan antara keduanya, kedudukan ibu yang sangat dominan dalam keluarga, hubuangan yang tidak terjalin baik antara orang tua dengan anaknya, kedatangan anak yang ditolak oleh ibu kandungnya (misalnya penolakan ibu ke anak yang lahir sebelum nikah), serta tidak terdapatnya wujud seorang bapak, dan kerenggangan ikatan antara anak serta bapaknya, kerap dikira jadi pemicu anak menjadi homoseksual.

2. Pengalaman intim kurang baik pada masa anak-anak.

Seorang anak yang pernah menghadapi pelecehan seksual serta kekerasan sangat berdampak berbahaya bagi kehidupannya kedepan, pada masa anak-anak akan menimnulkan anak tersebut menjadi seseorang Lesbian pada waktu dewasanya. Hasil riset dari Chicago, ialah Lauman, memperlihatkan seseorang yang sempat hadapi kekerasan seksual serta setelah itu menjadi gay sekitar 7,4\% serta 3,1\% perempuan yang menjadi Lesbian. Dari data tersebut menimbulkan bukti bahwa pengaruh kekerasan baik itu terjadi di kehidupan keluarga dan bermasyarakat.

3. Pengaruh lingkungan.

Asumsi lama yang kerap berkata "kepribadian seseorang bisa dikenali dari siapa teman-temannya" ataupun pengaruh lingkungan yang kurang baik bisa membuat seseorang bertingkah laku seperti dimana dia berada. Pergaulan bebas yang merupakan pengaruh lingkungan juga bisa menjadi pemicu seseorang memilih menjadi lesbian. Sebab minimnya mendapatkan perhatian baik itu dari orangtua atau masyarakat lingkungan sekitar, serta kasih sayang dari keluarga beresiko seseorang memilih untuk mencari perhatian serta kehidupan dari lingkungan sekitarnya, baik dari Cuma hanya mencari teman sampai mendapatkan perhatian serta kasih sayang yang tidak didapatkan dari dalam keluarga. Keputusan 
menjadi seorang Lesbian menjadikan orang seakan memperoleh kedamaian. Seluruh yang tidak pernah dirasakan dalam keluarga bisa diperoleh dari pasangan lesbinya. Sebab meski dalam ikatan Lesbian salah satu dari pendamping tersebut memposisikan dirinya selaku pria namun dia tetap wanita. Hanya saja yang membedakan hanyalah hormon pria dalam dirinya lebih menonjol dari pada hormon wanita, sehingga berpengaruh terhadap pribadinya (Tan, 2005: 56-60).

Dari ketiga faktor Lesbian di atas berdasarkan hasil penelitian di dapatkan bahwa faktor yang lebih dominan mereka menjadi seorang Lesbian karena pengaruh lingkungan. Lingkungan hasil wawancara didapat dari lingkungan salah berteman para informan.

\section{KESIMPULAN DAN SARAN}

\section{Kesimpulan}

Terkait realitas penyebab seseorang melakukan seksual Lesbian karena faktor lingkungan pergaulan, kurangnya pengawasan orang tua. Dengan menjadi seorang Lesbian mereka memiliki rasa kenyamanan dan eksplorasi terhadap lingkungan pergaulan para Lesbian.

Terkait representasi tidak ada seorangpun informan yang mengikuti komunitas ataupun kelompok-kelompok Lesbian yang ada di Bengkulu. Terkait representasi atau simbol Lesbian mereka tidak memiliki simbol khusus terkait pecinta sesama jenis.

Terkait Ideologi informan menyadari bahwa Lesbian merupakan penyimpangan sosial di masyarakat namun mereka tidak meninggalkan penyimpangan tersebut. Hal tersebut karena mereka mempunyai pandangan sendiri mengenai Lesbian yang di pandangan para Lesbian baik.

\section{Saran}

Setelah penulis memaparkan tentang representasi seksual Lesbian di kota Bengkulu, penulis ingin memberikan saran yaitu: Bagi Mahasiswa Dehasen Mahasiswa ilmu komunikasi Dehasen Bengkulu hendaklah selalu berhati-hati dalam pergaulan, sehingga tidak terjerumus dalam pergaulan yang salah. Bagi masyarakat Masyarakat diharapkan dapat memperhatikan lingkungan sekitar bila didapatkan penyimpangan sebaiknya cari penyelesaiannya. Nilai-nilai agama lebih baik ditingkatkan juga. 


\section{DAFTAR PUSTAKA}

Aan Komariah, Djam'an Satori. 2011. Metode Penelitian Kualitatif. Bandung: Alfabeta.

Az-Zulfi, Muhammad bin Ibrahim. 2005. Homoseks. Bandung: PT. Mizan Publika.

Budiarti, Lis Neni dan Agung EBW. 2011. Metodologi Penelitian DKV. Bandung: Institut Teknologi Bandung.

Danesi, Marcel. 2010. Pesan Tanda dan Makna : Buku Teks Dasar Mengenai Semiotika dan Teori Komunikasi. Yogyakarta: Jalasutra

Danesi, Marcel. 2012. Pesan, Tanda, dan Makna. Yogyakarta: Jalasutra.

Eriyanto. 2008. Analisis Wacana, Pengantar Analisis Teks Media. Yogyakarta: Lkis.

Hall, Calvin S and Lindzey, Gardner. 1997. Psikologi Kepribadian 1 Teori-teori Psikodinamik (Klinis). Yogyakarta: Kanisius.

Hawari, Dadang.2003. Islam dan Homoseksual. Jakarta Timur: Pustaka Zahra.

Husein Muhammad, et. all., 2011."Fiqh Seksualitas: Risalah Islam Untuk Pemenuhan Hak-Hak Seksualitas. Jakarta: BKKBN.

Kartono, K., 2009. Psikologi Abnormal Dan Abnormalitas Seksual. Bandung: CV Mandar Maju.

Mukhtar. 2013. Metode Penelitian Deskriftif Kualitatif. Jakarta : GP Press Group

Mutmainnah, M.B. \& Ismi. 2012. Perilaku Komunikasi Antarpribadi Pasangan Gay di Kota Makassar. Skripsi. Makassar : Universitas Hasanuddin

Nadia, Zunly. 2005. Waria Laknat atau Kodrat?. Yogyakarta : Pustaka Arwa.

Nuraini Juliastuti, Representasi, Newsletter KUNCI No. 4, Maret 2000 http://Kunci.or.id/esai/nws/04/Representasi.htm. Diakses pada tanggal 28 Maret 2020

Oetomo, D. 2011. Gay di Masyarakat. Surabaya : Gaya Nusantara

Osira, Yessilia. dkk. 2017. Kehidupan Rentan Komunitas LGBT di Curup Rejang Kabupaten Lebong Provinsi Bengkulu. Jurnal

Papilaya. 2016. Lesbian, Gay, Biseksual, Transgender dan keadilan Sosial. Jurnal Humaniora Vol III. No.1

Piliang, Yasraf Amir. 2003. Hipersemiotika, Tafsir Cultural Studies Atas Matinya Makna. Yogyakarta: Jalasutra

Puspitorini \& Pujileksono. 2005. Perilaku Manusia (Pengantar Singkat Tentang Psikologi). Bandung: PT Refika Aditama.

Riduwan. 2010. Skala Pengukuran Variabel-variabel Penelitian. Bandung: Alfabeta.

Rizal, Khairul. 2016. Penanggulangan LGBT (Lesbian, ).

Sa"abah, Marzuki Umar. 1998. Seks dan Kita. Jakarta : Gema Insani Ekspres

Sadarjoen, Sawitri, S. 2005. Kasus Gangguan Psikoseksual. Bandung: Refika Aditama.

Saryati, Asih. 2012. Latar Belakang Perilaku Lesbian (Studi Kasus Pada Pasangan Lesbian). Skripsi . Yogyakarta: UIN Sunan kalijaga Yogyakarta

Siahaan M. S. Jokie. 2009. Perilaku Menyimpang Pendekatan Sosiolog. Jakarta: PT. INDEKS.

Soekanto, Soerjono. 2004. Sosiologi Keluarga: tentang Ihwal Keluarga, Remaja dan Anak. Jakarta: PT. Rineka Cipta.

Sugiyono. 2017. Metode Penelitian Kuantitatif, Kualitatif, dan R\&D. Bandung : Alfabeta.

Sukmadinata, Nana Syaodih. 2007. Metode Penelitian Pendidikan. Bandung: Rosdakarya.

Susanti, Anita dan Mochamad Widjanarko. 2015. Fenomena Cinta Lesbian. Jurnal

Weeks, Jeffer. 1986. Sexuality. Ellis Korwood-Tavistock Publicationals.

Wibowo, Indiwan Seto Wahyu. 2011. Semiotika Komunikasi : Aplikasi Praktis Bagi Penelitian dan Skripsi Komunikasi. Jakarta : Mitra Wacana Media 